Queer Narratives of the Caribbean Diaspora 


\section{Queer Narratives of the Caribbean Diaspora}

\section{Exploring Tactics}

\section{Zoran Pecic}

Lecturer, Department of Culture and Identity, Roskilde University, Denmark

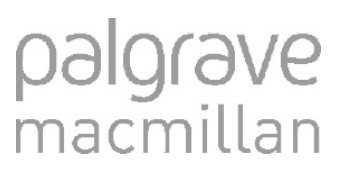




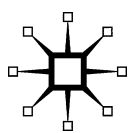

(C) Zoran Pecic 2013

All rights reserved. No reproduction, copy or transmission of this publication may be made without written permission.

No portion of this publication may be reproduced, copied or transmitted save with written permission or in accordance with the provisions of the Copyright, Designs and Patents Act 1988, or under the terms of any licence permitting limited copying issued by the Copyright Licensing Agency, Saffron House, 6-10 Kirby Street, London EC1N 8TS.

Any person who does any unauthorized act in relation to this publication may be liable to criminal prosecution and civil claims for damages.

The author has asserted his right to be identified as the author of this work in accordance with the Copyright, Designs and Patents Act 1988.

First published 2013 by PALGRAVE MACMILLAN

Palgrave Macmillan in the UK is an imprint of Macmillan Publishers Limited, registered in England, company number 785998, of Houndmills, Basingstoke, Hampshire RG21 6XS.

Palgrave Macmillan in the US is a division of St Martin's Press LLC, 175 Fifth Avenue, New York, NY 10010.

Palgrave Macmillan is the global academic imprint of the above companies and has companies and representatives throughout the world.

Palgrave ${ }^{\circledR}$ and Macmillan ${ }^{\circledR}$ are registered trademarks in the United States, the United Kingdom, Europe and other countries.

ISBN 978-1-349-34961-6

ISBN 978-1-137-37903-0 (eBook)

DOI $10.1057 / 9781137379030$

This book is printed on paper suitable for recycling and made from fully managed and sustained forest sources. Logging, pulping and manufacturing processes are expected to conform to the environmental regulations of the country of origin.

A catalogue record for this book is available from the British Library.

A catalog record for this book is available from the Library of Congress. 


\section{Contents}

Acknowledgements

vi

Introduction 1

1 Queer Tactical Diaspora and the Caribbean Space 7

2 Shani Mootoo's Diasporas 36

3 The Movements of Dionne Brand 102

4 Queering the Bildungsroman 134

5 Reshaping the Past in Lawrence Scott's Aelred's Sin 158

$\begin{array}{ll}\text { Conclusion } & 178\end{array}$

$\begin{array}{ll}\text { Notes } & 183\end{array}$

$\begin{array}{lr}\text { Bibliography } & 189\end{array}$

$\begin{array}{ll}\text { Index } & 194\end{array}$ 


\section{Acknowledgements}

I have many people to thank for helping me through the process of writing this book. First and foremost, none of this would have been possible without the help and support of Justin Edwards, who supervised my doctoral research at Bangor University. This book began as a thesis, and it was his outstanding advice, excellent support and great friendship that made this book possible. Without him, this book would never have been written. I would also like to thank my colleagues at Roskilde University, particularly Dr Lars Jensen. Their encouragement and advice got me through the difficult parts of the project. Dr Jensen's suggestions greatly strengthened my work. I am infinitely grateful to my friends for their emotional and intellectual support. Without them, the process of writing this book would have been so much more difficult. I would like to thank my parents, Ljiljana and David, for their financial and emotional backing. I want to express my love to Sunam Lee. This would not have been possible without your love and support. Finally, I would like to thank Ben Doyle and Sophie Ainscough at Palgrave Macmillan as well as the anonymous readers for their thoughtful and constructive criticism. 